\title{
„Jesteśmy straconym pokoleniem”. Wspólnoty Żydów birobidżańskich w Izraelu: relacja z badań terenowych (lipiec 2012 r.)
}

W ramach przygotowywanej pracy doktorskiej zajmuję się badaniami nad wspólnotami, które wyemigrowały do Izraela z Żydowskiego Obwodu Autonomicznego na rosyjskim Dalekim Wschodzie. Badania prowadzę od 2010 roku. Rozpoczęłam je rekonesansem badawczym w Birobidżanie - stolicy Żydowskiego Obwodu Autonomicznego. W trakcie tych badań zgromadziłam dokumentację fotograficzną architektury miasta, przeprowadziłam kilka wstępnych wywiadów oraz kwerendę w miejscowej bibliotece. W lipcu 2012 roku odbyłam w Izraelu kolejny etap badań terenowych na temat wspólnot emigrantów z Żydowskiego Obwodu Autonomicznego. W trakcie tego pobytu nagrałam 16 rozmów z byłymi mieszkańcami Birobidżanu. Następna wyprawa terenowa zaplanowana została na sierpień - wrzesień 2013 r. i będzie koncentrowała się na docieraniu do Żydów birobidżańskich, którzy zamieszkują na północy Izraela.

\section{Historia powstania Żydowskiego Obwodu Autonomicznego'}

Żydowska jednostka terytorialna na Dalekim Wschodzie w ZSRR powstała 20 sierpnia 1930 roku, kiedy utworzono Żydowski Rejon Narodowy, a później - 7 maja 1934 r. - mocą uchwały Centralnego Komitetu Wykonawczego ZSRR powołano do życia Żydowski Obwód Autonomiczny. Obwód istnieje do dnia dzisiejszego. Położony jest u zbiegu rzek Biry i Bidżan (stąd nazwa stolicy ŻOA - Birobidżan). Jak pisze Artur Patek, autor jedynej dotychczas polskiej monografii o Birobidżanie: „,Jego granice wyznaczały w przybliżeniu: rzeka Amur na południu (...) obwód chabarowski na wschodzie (...), amurski na zachodzie oraz kolej transsyberyjska na północy" [Patek 1997 : 23].

Propaganda radziecka chętnie podkreślała, że obszar Birobidżanu był większy niż niektórych państw europejskich. Po początkowych zmianach jego powierzchnia wyniosła z czasem około 36 tys. km² [Patek 1997: 23].

${ }^{1}$ Dzieje ŻOA i traumatyczne doświadczenia mieszkańców zostały szerzej omówione w odrębnym artykule [Makarowa, Sawaniewska-Mochowa 2010], w którym jest podana ważniejsza literatura przedmiotu. 
Nie był to bynajmniej pierwszy projekt żydowskiej kolonizacji w ZSRR. Wcześniej na skutek tzw. korenizacji, która nastąpiła jako odpowiedź na zalecenia X Zjazdu RKP(b) W 1921 roku, zostały utworzone żydowskie rady miejskie i wiejskie oraz wyższe formy żydowskiej autonomii - rejony narodowościowe. Do 1935 r. powstało pięć rejonów: Kalinindorf, Nowy Złatopol i Stalindorf na Ukrainie oraz Frajdorf i Łarindorf na Krymie.

Utworzenie autonomicznej jednostki żydowskiej na Dalekim Wschodzie miało przede wszystkim znaczenie polityczne. Zgodnie z definicją ówczesnego przywódcy ZSRR Józefa Stalina naród była to „wytworzona historycznie trwała wspólnota ludzi, powstała na gruncie wspólnoty języka, terytorium, życia ekonomicznego i układu psychicznego, przejawiająca się we wspólnocie kultury" [Stalin 1949: 303].

Zgodnie z tą definicją Żydzi nie mogli być nazwani narodem, bo nie mieli własnego terytorium. Zrzeszali się jednak w stowarzyszeniach syjonistycznych, zabiegając o wyjazd do Palestyny. Utworzenie żydowskiej jednostki autonomicznej miało odwrócić ich uwagę od Palestyny, a jednocześnie uczynić z nich naród, który „zajmie właściwe miejsce w budownictwie socjalistycznym" [Patek 1997: 21]. Decyzję o rozpoczęciu żydowskiej koIonizacji na Dalekim Wschodzie podjęto wbrew raportowi profesora B. Ł. Bruka, którego ekspedycja zbadała wybrany teren i opisała go jako nienadający się do życia ze względu na trudne warunki klimatyczne i środowiskowe. Niemniej, jak podaje Arno Lustiger, zasiedlenie tych terenów było bardzo korzystne dla władzy radzieckiej, gdyż rozwiązywało kilka problemów jednocześnie: ,,zwiększone bezpieczeństwo pogranicza, zaspokojenie dążenia wielu Żydów do posiadania «własnego» terytorium (...) i wreszcie - można było liczyć się z tym, że niepowodzenie projektu będzie można wykorzystać jako ostateczny argument odrzucenia kolonizacji np. na Krymie" [Lustiger 2004: 90-91].

Birobidżan mimo wielkich starań władz radzieckich nigdy nie stał się jednostką naprawdę żydowską. Żydzi nigdy nie stanowili tam większości, a w latach 90., po wielkiej fali emigracyjnej do Izraela, stali się wręcz mniejszością narodową. Właśnie emigranci z Birobidżanu, którzy znaleźli się w Izraelu, są przedmiotem mojego zainteresowania na prezentowanym etapie badań.

\section{Geografia i metoda badań. Pytania badawcze}

Wszyscy moi rozmówcy należą do starszego, czyli drugiego pokolenia birobidżańskich przesiedleńców. Przyjechali do ŻOA wraz z rodzicami jako małe dzieci lub urodzili się tam w latach 30. XX wieku. Spędzili w ŻOA młodość oraz dorosłe życie i wyemigrowali powtórnie na początku lat 90., często za swoimi dziećmi, tym razem do Izraela. Osiedlili się tam 
Relacje z badań

w różnych miastach. Najwięcej byłych mieszkańców Birobidżanu zamieszkuje obecnie na północy i południu kraju, w miastach Maalot, Naharija, Be’er Szewa oraz okolicach Hajfy.

Poszukiwania rozmówców odbywały się dwutorowo. Po przybyciu do Izraela zamieściłam na lokalnej rosyjskojęzycznej stronie internetowej ogłoszenie, że poszukuję emigrantów z Birobidżanu, potem zaś wykorzystywałam również metodę śnieżnej kuli i z polecenia poprzednich informatorów spotykałam się z kolejnymi. Ta druga metoda okazała się skuteczniejsza - dzięki niej znalazłam 14 z 16 informatorów.

W trakcie badań przeprowadzałam wywiady narracyjno-biograficzne (łącznie około 20 godzin²). Prowadziłam również obserwację uczestniczącą, często spędzałam z moimi rozmówcami cały dzień, biorąc udział w rodzinnych posiłkach oraz obserwując codzienne życie rodziny.

Stosowałam metodologię charakterystyczną dla badań językowo-antropologicznych. Jak pisze w monografii Polska mniejszość na Litwie Kowieńskiej. Studium socjolingwistyczne Anna Zielińska: „(...) jednostki są reprezentantami swoich grup. Procesy historyczne i społeczne z jednej strony wpływają na życiorys i poglądy jednostki, z drugiej zaś indywidualne emocje i czyny mają wpływ na owe procesy. Treści relacji zawierają informacje o stosunku informatora do swojej społeczności i kultury, do obcych kultur, ocenę wydarzeń historycznych i współczesnych. Analizując autobiografie i zawarte w nich poglądy, badacz ma możliwość poznania «od wewnątrz» warunków życia charakterystycznych dla całej zbiorowości” [Zielińska 2002: 10].

Prowadząc wywiady, próbowałam znaleźć odpowiedzi na następujące pytania:

- skąd przybywali do Birobidżanu emigranci oraz z jakich środowisk pochodzili?

- czy życie w Birobidżanie było reglamentowane przez nakazy i zakazy religijne?

- jaką rolę w życiu społeczności żydowskiej odgrywał język jidysz oraz w jakim stopniu znany był język hebrajski?

- jak mieszkańcy ŻOA postrzegają Zagładę oraz II wojnę światową?

- jaki jest ich stosunek do stalinizmu i sowietyzacji?

- czy w ŻOA istniał antysemityzm? Jeśli tak, to jak się przejawiał?

- co zmusiło te osoby do emigracji do Izraela?

W niniejszym artykule skupiam się głównie na przyczynach emigracji moich rozmówców do Żydowskiego Obwodu Autonomicznego oraz na sytuacji językowej, panującej w ich środowisku.

2 Prowadzone wywiady miały (wzorem wywiadów antropologicznych i etnograficznych) charakter elastyczny, lekko ukierunkowany [por. Hammersley, Atkinson 2000: 131-162]. 


\section{Charakterystyka rozmówców}

Jak już była mowa wyżej, zarejestrowałam 16 pogłębionych wywiadów o dość zróżnicowanej tematyce, która często pojawiała się spontanicznie z inicjatywy samych rozmówców. Byli oni zresztą pozytywnie zaskoczeni, że interesuje się ich losami badaczka z Polski, która w dodatku komunikuje się z nimi po rosyjsku. Nie kreowałam w zamierzony sposób swojego wizerunku, dokładnie wyjaśniałam natomiast cel moich badań i nie unikałam odpowiedzi na pytania dotyczące mojej osoby, czym zdobyłam zaufanie rozmówców.

Wywiady przeprowadzałam z mieszkańcami następujących miast: Kiryat Bialik, Kiryat Motzkin, Nahariya, Jerozolima, Bat Yam i Be’er Szewa. Trop jerozolimski okazał się jednak pomyłką, ponieważ mój rozmówca, owszem, bywałw Birobidżanie, ale tylko przejazdem - jego pułk w czasie Wielkiej Wojny Ojczyźnianej stacjonował na granicy z Japonią. W innych miastach już po przeprowadzonych wywiadach udało mi się uzyskać informacje o kolejnych osobach, które chciałyby ze mną porozmawiać. Szansę na poszerzenie bazy materiałowej i zarejestrowanie nowych opowieści zamierzam wykorzystać jeszcze w tym roku.

Większość moich dotychczasowych rozmówców nie zastrzegła anonimowości, dlatego mogę przedstawić krótkie charakterystyki tych spośród nich, z którymi wywiady już przetłumaczyłam i opracowałam na potrzeby mojej rozprawy doktorskiej. Przy dalszej analizie wykorzystuję również transkrypcje wywiadów z osobami, które nie chciały ujawnić swojej tożsamości, dlatego używana przeze mnie sygnatura będzie się składała wyłącznie z symbolu płci rozmówcy i numeru wywiadu.

\begin{tabular}{|l|c|l|l|l|}
\hline Imię, otczestwo, nazwisko & $\begin{array}{c}\text { Rok uro- } \\
\text { dzenia }\end{array}$ & $\begin{array}{c}\text { Miejsce zamieszka- } \\
\text { nia w Izraelu }\end{array}$ & \multicolumn{1}{|c|}{ Zawód } & $\begin{array}{c}\text { Skąd przyjechał(a) } \\
\text { do ŻOA? }\end{array}$ \\
\hline $\begin{array}{l}\text { Туня Шмулевна Пинзур } \\
\text { (Бондарь) }\end{array}$ & 1932 & Kiryat Bialik & - & Winnica (Ukraina) \\
\hline $\begin{array}{l}\text { Григорий Израилович } \\
\text { Пинзур }\end{array}$ & 1932 & Kiryat Bialik & Rybak & Białoruś \\
\hline $\begin{array}{l}\text { Семён Гершевич } \\
\text { (Григорьевич) }\end{array}$ & 1939 & Kiryat Motzkin & Pracownik kultury & Urodził się w ŻOA \\
\hline $\begin{array}{l}\text { Мария Захаровна } \\
\text { Шортова (Липец) }\end{array}$ & 1922 & Kiryat Motzkin & Nauczycielka & Berdyczów (Ukraina) \\
\hline Мая Венгрова-Миндель & 1924 & Nahariya & Nauczycielka & Berdyczów (Ukraina) \\
\hline $\begin{array}{l}\text { Сара Евсеевна Браверман } \\
\text { (Живелик) }\end{array}$ & 1922 & Be'er Szewa & $\begin{array}{l}\text { Dziennikarka, pra- } \\
\text { cowniczka radia }\end{array}$ & Humań (Ukraina) \\
\hline $\begin{array}{l}\text { Алла (Эльза) Аврамовна } \\
\text { Блехерман (Бродская) }\end{array}$ & 1935 & Bat Yam & Nauczycielka & $\begin{array}{l}\text { Urodziła się w stoli- } \\
\text { cy ŻOA, Birobidżanie }\end{array}$ \\
\hline Изя Ильявич Блехерман & 1935 & Bat Yam & - & $\begin{array}{l}\text { Urodził się w stolicy } \\
\text { ŻOA, Birobidżanie }\end{array}$ \\
\hline
\end{tabular}


Wymienieni rozmówcy należą do najstarszego obecnie pokolenia birobidżańczyków, którzy albo jako dzieci przyjechali z rodzicami do Birobidżanu, albo też urodzili się w żOA. Wszyscy wyemigrowali do Izraela pod koniec lat 80. lub na początku lat 90. XX wieku wraz z wielką aliją - masową emigracją Żydów radzieckich do kraju przodków. Najczęściej, jako osoby starsze, jechali za swoimi dziećmi, które nie chciały zostawać same w Rosji.

\section{Przyczyny przeprowadzki do Birobidżanu}

Każdy z wywiadów rozpoczynał się od wspomnień o drodze do Birobidżanu (czasem również z Kresów II RP) oraz od rozważań na temat, dlaczego się tam jechało i czy z perspektywy czasu to miało sens. Większość rozmówców dochodziła do wniosku, że najważniejszą przyczyną, która skłaniała Żydów radzieckich oraz sympatyzujących z socjalizmem Żydów z innych państw do tak dalekiej podróży, była chęć zarobku i poprawy warunków życia.

M1²: Na Daleki Wschód przyjechaliśmy w trzydziestym dziewiątym roku. Mój tata... no i przyjechaliśmy. Jak to się nazywa, kiedy wszyscy Żydzi jechali?

M.M. ${ }^{4}$ : Przesiedlenie?

K1: Tak, przesiedlenie.

M1: Przesiedlenie... No i znaczy się jechali tam zarobić. Tam ulgi były i fabrykę otwierano. I najechało się z Ukrainy bardzo dużo stolarzy. Żeby zarobić kopiejkę.

K1: No i w 31. roku w Związku Radzieckim odbył się NEP. Tata stracił pracę. I wyjechaliśmy wtedy - była duża propaganda za Birobidżanem - no i pojechaliśmy. Jeździliśmy przez cały miesiąc, w takich bydlęcych wagonach. (...) No jeździliśmy. Przyjechaliśmy do Birobidżanu, wyszliśmy na dworzec. Dworzec jak dworzec, nieduży. Zeszliśmy na ziemię i od razu błoto do kolan.

M2: Myślę, że nikomu ta historia już nie jest potrzebna, bo żOA - to, oczywiście, jakby to powiedzieć, wymysł, na który dali się złapać niektórzy żydzi w latach 20. - 30. Na taką iluzję, haczyk. Dlatego, że niektórzy z nich biedowali i ta bieda ich gnała za lepszym życiem. (...) Oni wszyscy jechali za lepszym życiem, myśleli, że... (...) Moja matka przyjechała jakoś w roku $1930-1932$, dokładniej nie powiem. Też pojechała. Ona była krew z mlekiem, przy kości, miała 35 lat, niezamężna. Nie jechali za sloganami, tylko dlatego, że byli zmuszeni przez życie. Biedowali, umierali z głodu. (...) Ale wszyscy się oszukali.

\footnotetext{
${ }^{3} \mathrm{M}$ - mężczyzna, $\mathrm{K}$ - kobieta; 1,2 itd. - nadany numer rozmówcy.

${ }^{4}$ M.M. - Maria Makarowa.

${ }^{5}$ Wszystkie wywiady przytaczam w tłumaczeniu własnym z języka rosyjskiego, starając się zachować oralność wypowiedzi. Zdaję sobie sprawę z tego, że niektóre walory językowe tych wywiadów przy tłumaczeniu niestety zostają utracone.
} 
W domach niektórych z moich informatorów zaobserwowałam zjawisko, które roboczo nazywam „ołtarzykami birobidżańskimi”. W jakimś ważnym, wyróżnionym w przestrzeni domowej miejscu, często obok świeczników, menor czy ikon, są umieszczone fotografie z Birobidżanu, obrazki z krajobrazami tamtych terenów, pamiątki z ŻOA, książki oraz albumy fotograficzne. Podkreśla to rolę, którą nadal odgrywa więź z Birobidżanem w tożsamości moich rozmówców.

K2: Oj, wszyscy moi znajomi mówią, że ja jestem nienormalna.

M.M.: Dlaczego tak mówią?

K2: Bo wiesz, ja gdzieś jadę, a oni do mnie: „Co, znów pewnie pojechałaś do Birobidżanu?"

Birobidżan nadal pozostaje dla moich rozmówców przestrzenią sakralną, utraconą ojczyzną. Wielokrotnie w wywiadach podkreślają nostalgię, którą odczuwają, chęć ponownego wyjazdu na Daleki Wschód, by odwiedzić znajomych i krewnych.

\section{Organizacje birobidżańskie w Izraelu}

Zagadnieniem najbardziej interesującym mnie w trakcie badań było funkcjonowanie emigrantów z Birobidżanu w Izraelu, a także ich doświadczenia z przeszłości dotyczące używanych przez nich języków oraz stosunku do judaizmu. Podczas planowania tego etapu badań liczyłam na przeprowadzenie wywiadów z pojedynczymi osobami, które w Izraelu funkcjonują w oderwaniu od birobidżańskiej przeszłości. Ciekawiły mnie przede wszystkim historie życia poszczególnych osób. Jednak szybko udało mi się ustalić, że birobidżańczycy w Izraelu zrzeszają się w dość prężnie działające stowarzyszenia, wydają pisma, organizują wydarzenia promujące Żydowski Obwód Autonomiczny. W lipcu udało mi się dotrzeć do przedstawicieli dwóch takich organizacji.

Jedna z nich - Negewskie Stowarzyszenie Emigrantów z Birobidżanu - działa na południu Izraela. Jej przedstawiciele mieszkają głównie w mieście Be’er Szewa oraz w innych mniejszych miejscowościach. Zarząd tej organizacji tworzą byli partyjni działacze stolicy ŻOA - m.in. Władimir Rotensztein, były kierownik Działu Propagandy w Komitecie Miasta, następnie Dyrektor Radia w Birobidżanie. Członkowie stowarzyszenia, dążąc do umacniania wspólnotowości grupy, organizują wycieczki, spotykają się na wieczorach tematycznych, a także obchodzą kolejne rocznice powstania ŻOA. We wrześniu 2012 roku w Centrum Kultury Rosyjskiej, działającym przy Ambasadzie Rosji w Tel Awiwie, obchodzono 75. rocznicę powołania żydowskiej autonomii w Birobidżanie. Interesujące, że spotkanie odbyło 


\section{Relacje z badań}

się właśnie w tym miejscu, niejako na rosyjskim gruncie kulturowym i w dodatku - jak wynika z publikacji internetowych - w języku rosyjskim ${ }^{6}$. Również legitymacje członkowskie stowarzyszenia są świetnym przykładem „mocy” tożsamościowej, jaką ma ciągle język rosyjski dla emigrantów z Birobidżanu. Na pierwszej stronie legitymacji wszystkie podstawowe dane (imię, nazwisko, adres, telefon) są podawane w dwóch językach, po rosyjsku i hebrajsku, natomiast sama nazwa organizacji, jej adres oraz składki członkowskie są już zapisane wyłącznie po rosyjsku. Wywnioskować można, że hebrajski pełni tu raczej funkcję symboliczną - ozdabia legitymację organizacji żydowskiej. Natomiast niewątpliwie funkcję użytkową oraz tożsamościową spełnia język rosyjski.

Kolejna organizacja zrzeszająca birobidżańczyków działa na południu Izraela, w Maalocie. Maalot jeszcze w czasach schyłku ZSRR był miastem partnerskim Birobidżanu i właśnie tu osiedlali się pierwsi emigranci radzieccy. Organizacja ta prowadzi aktywną działalność wydawniczą. Opublikowała m.in. książeczkę Весь Биробиджан [Cały Birobidżan], która jest swego rodzaju przewodnikiem po diasporze birobidżańskiej w Izraelu, a nawet $w$ innych krajach (USA, Kanadzie). Wydana jest oczywiście po rosyjsku. Autorzy tego tomu - Maja i Michaił Kotlerman (rodzice pracownika Uniwersytetu w Bar llanie dr. Bera [Borisa] Kotlermana, który poświęcił Birobidżanowi swoją działalność naukową) - skrupulatnie zbierają telefony i adresy byłych birobidżańczyków, publikują również informacje o usługach wykonywanych przez te osoby (masaż, pomoc prawnicza, konsultacje lekarskie itp.), zamieszczają wiersze i wspomnienia swoich rodaków, a także fragmenty opracowań historii żOA.

Prezentowane wydawnictwo to nie tylko znakomite źródło do badania mechanizmów umacniania wspólnotowości grupy, ale przede wszystkim swoisty drogowskaz, jak do rozmówców dotrzeć. Wiadomo przecież, że pierwszym zadaniem badacza pracującego w terenie jest, jak to określają Hammersley i Atkinson [2000: 65], ,wejście do środowiska” i zawarcie korzystnych znajomości. Zbiorek Kotlermanów zawiera cenne informacje (adresy, telefony), które są ujawniane bez zachowania jakichkolwiek zasad ochrony danych osobowych. Wynika to zapewne z tego, że wydawnictwo jest przeznaczone do użytku wewnątrz wspólnoty emigrantów z Birobidżanu. Autorzy tłumaczą we wstępie potrzebę publikowania szczegółowych informacji o mieszkających w Izraelu birobidżańczykach chęcią wzajemnego poznania się i ocalenia pamięci o opuszczonej ojczyźnie:

Drodzy Rodacy! Z biegiem czasu, w zawierusze nowego życia, nowych problemów, coraz rzadziej myślami wracamy tam, gdzie została nasza młodość, dojrzałość, gdzie dorastały nasze dzieci, gdzie zostały groby drogich nam osób... O wielu rzeczach trzeba sobie przypomnieć, o wielu rzeczach porozmawiać. Znajdując się wiele kilometrów od

\footnotetext{
${ }^{6}$ http://newswe.com/index.php?go=Pages\&in=view\&id=5313 (dostęp: 1.06 .2013 ).
} 
Birobidżanu, robimy to w pojedynkę. Właśnie te refleksje doprowadziły nas do pomysłu, by zebrać informacje o wszystkich rodakach w jednym zbiorku, opowiedzieć, gdzie i jak żyją, o czym myślą, czym się zajmują. Oczywiście, to, co zrobiliśmy, to tylko mała część. Bardzo chciałoby się wiedzieć o każdym. Będziemy wdzięczni, jeżeli zadzwonicie, powiecie coś o sobie [Котлерман (red.) 2010: 3]

\section{Sytuacja językowa - sfery użycia jidysz, rosyjskiego i hebrajskiego. Stosunek do judaizmu}

Dwujęzyczność jest cechą charakterystyczną Birobidżanu. Jidysz od początku był językiem uprzywilejowanym i tolerowanym przez władzę radziecką. Miał on w środowiskach żydowskich całkowicie zastąpić język hebrajski (jako język religii) i doprowadzić do ich stopniowej laicyzacji. Po X Zjeździe Partii powstały liczne kluby, biblioteki żydowskie, a także szkoły z jidysz jako językiem wykładowym oraz prasa w tym języku. „,jidyszyzacja” była także charakterystyczną cechą polityki w Żydowskim Obwodzie Autonomicznym. Jidysz nadano status języka urzędowego. Dążono do zideologizowania kultury żydowskiej, a więc do wynarodowienia Żydów w przyszłości. Otwierano liczne placówki kulturalno-oświatowe, angażujące ludność żydowską w różne formy działalności. Był to sposób na oderwanie Żydów od religii, chociaż właśnie rozwój kultury żydowskiej, jednak dość mocno przesiąkniętej judaizmem, zahamował procesy wynaradawiające.

W Birobidżanie wychodziło kilka gazet w języku jidysz. Na fali entuzjazmu wywołanego przez propagandę towarzyszącą powstaniu ŻOA, osiedliło się tu wielu pisarzy tworzących w jidysz - Meir Alberton, Dawid Bergelson, Izaak Bronfman, Emanuel Kazakiewicz, Boris Miller, Lubow' Wasserman i inni.

Można śmiało powiedzieć, że jidysz w ŻOA nigdy nie zdominował języka rosyjskiego, mimo licznych uproszczeń i stworzenia sowieckiej odmiany jidysz (czyli zapisu fonetycznego wszystkich słów, w tym hebraizmów, niestosowania końcowych form liter i in.). Jednak do dzisiaj napisy w jidysz, napisy w języku rosyjskim stylizowane na jidysz oraz jidyszyzmy i hebraizmy są obecne w przestrzeni miejskiej Birobidżanu.

Podczas tego etapu badań terenowych interesowała mnie kwestia, w jakim zakresie w Birobidżanie używano języka jidysz i czy najstarsi emigranci oraz następne pokolenia ich rodzin w Izraelu jeszcze w tym języku się komunikują. Bardzo ważnym problemem badawczym było też ustalenie funkcji języka rosyjskiego. Wszyscy moi rozmówcy chętnie wspominali w tym właśnie języku oraz przytaczali fragmenty rosyjskich piosenek.

\footnotetext{
${ }^{7}$ Podaję we własnym tłumaczeniu z języka rosyjskiego.
} 
Relacje z badań

Zakres znajomości języka jidysz już w Birobidżanie był ograniczony pokoleniowo. Najstarsi rozmówcy wynieśli go z domu, natomiast ci, którzy urodzili się już w żOA, najczęściej jidysz słyszeli, ale nigdy w tym języku nie rozmawiali, ani też specjalnie nie chcieli się go uczyć.

M2: To wszystko było fałszywe. My oprócz szyldów, że tam Birobidżan w jidysz jest napisany, no i książek, no i biblioteka...

M.M.: A w bibliotece były książki w jidysz?

M2: Oczywiście! Ale kto to czytał? Nikt tego nie czytał! Nawet nie uczyliśmy się jidysz, nie znaliśmy go!

M.M.: A mama Pana nie uczyła?

M2: Mój problem w tym, że moja mama rozmawiała z nami, z dziećmi, tylko po rosyjsku.

M.M.: A słyszał Pan, żeby coś mówiła w jidysz?

M2: Oczywiście! Znam troszeczkę jidysz. Wiem, że jak sąsiadki przychodziły, to między sobą tylko w jidysz, zapamiętywałem wyrazy, tak mniej więcej 30\% rozumiem. Oczywiście, gdybym chciał, mógłbym nauczyć się jidysz sam. Tak jak teraz hebrajskiego. Co, nie mógłbym? W głowach nam poprzewracali, że ten język nie jest nam potrzebny. Skończycie, pójdziecie na uczelnię, a na uczelni po rosyjsku wszystkie. No, a jak pracowałem, to byłem jedynym żydem na stu Rosjan. No i na co mi potrzebny ten jidysz?

Mimo tej ograniczonej dystrybucji jidysz w przestrzeni prywatnej, niektórzy moi rozmówcy uważali, że język ten, podobnie jak hebrajski, jest zarezerwowany tylko dla Żydów. Przypisywali mu zatem funkcję emblematyczną, odróżniającą jego użytkowników od innych grup etniczno-narodowych. Za niedopuszczalne, naruszające wręcz sferę sacrum językowego, uznano zachowanie pewnego Ukraińca, który samodzielnie nauczył się jidysz i prowadził lekcje tego języka w radiu:

M3: A ja pamiętam taką sytuację w radiu. Występował u nas jeden muzyk, bardzo dobrze go pamiętam, Szmatko on. Ale on Ukrainiec, nic wspólnego z żydostwem nie miał. Ale on samodzielnie nauczył się jidysz i w radiu dawał lekcje jidysz. Ukrainiec, nigdy w życiu nie mówił w jidysz i w radiu dawał lekcje jidysz! Przecież to profanacja!

W odczuciu niektórych z moich rozmówców jidysz jest uznawany za język pomocny, ułatwiający życie na emigracji w Izraelu. Wydaje się, że jidysz w ich świadomości znowu przejmuje funkcję języka hebrajskiego, którym większość z nich nie włada. Jest to wich poczuciu ogólny język żydowski.

M1: Teraz nawet rosyjskie dzieci chodzą, uczą się jidysz. Rodzice ich posyłają. No nie wiem. Może, żeby jak przyjadą do Izraela, już znali język... 
W opinii innych jidysz jest językiem umierającym lub już martwym. Wskrzeszenie tego języka jest - ich zdaniem - sprawą bezsensowną, ponieważ już w Birobidżanie ten język umierał, a teraz ostatecznie zniknie wraz z najstarszym pokoleniem birobidżańczyków.

M2: No i teraz są w Birobidżanie ludzie, którzy, znaczy się, uczą się jidysz, mówią w jidysz. Ale to się nazywa, wiesz, wskrzeszać nieboszczyka. To jest martwa sprawa. To już jest zniszczone, rozdeptane.

Choć ocena użyteczności jidysz różni Żydów z Birobidżanu, to obserwacja praktyki językowej w różnych środowiskach w Izraelu uzmysławia, że w sytuacji, gdy rozmówca pochodzący z Rosji nie zna hebrajskiego, a potrafi posłużyć się jidysz, otwiera mu to dostęp do rozmaitych organizacji społecznych. Żyd emigrant mówiący w jidysz zasługuje na większe uznanie społeczne i w dość wyraźnie zarysowującym się podziale społeczeństwa w Izraelu na Żydów i nie-Żydów sytuowany jest jako ktoś bardziej swój niż obcy Najbardziej prestiżowa jest oczywiście znajomość hebrajskiego.

M1: Tu starsze osoby - idziesz, słyszysz, że mówią w jidysz. Jeden z przyjemnością się rozgada, drugi - a bysele, a bysele - czyli troszeczkę, ale on rozumie...

M4: Tu, jeżeli powiesz w jidysz, oni na twarzy się zmieniają, gotowi są we wszystkim pomóc.

K3: Jidysz to dowód, że rodzina jest żydowska.

Czasami jidysz służy w różnych sytuacjach komunikacyjnych (w rodzinie, w kręgu towarzyskim) do kodowania wypowiedzi. Może to prowadzić także do zabawnych sytuacji, gdy rozmówcy chcąc przed kimś utajnić treść komunikatu, używają jidysz, a trafiają na Żyda, który rozumie sens ich wypowiedzi. Warto zauważyć, że w toku wywiadów moi informatorzy w sposób bardzo swobodny mieszają relacje czasoprzestrzenne. Zatem część z opowiadanych przez nich historii dotyczy Birobidżanu, do którego chętnie wracają pamięcią.

K1: Siedzi szewc na ulicy, ja do niego podeszłam. On mi naprawia buciki i mówi do swojego znajomego w jidysz: «Oj, jaka ładniutka dziewczyna, jakie cycuszki ma fajne!». A ten do niego: «Sza! Przecież to żydowskie dziecko!» (śmiech).

Język hebrajski jest moim najstarszym rozmówcom najczęściej nieznany, niektórzy przyswoili tylko podstawowe słownictwo. Nieznajomość języka sacrum, a jednocześnie całkowite wyrwanie ich z tradycji judaizmu, sprawiają, że czują się obco wśród innych Żydów.

\footnotetext{
8 Por.: Ruscy w Izraelu sq skazani na bycie obcymi http://inosmi.ru/asia/20110102/165288006.html (dostęp: 2.07.2013).
} 


\section{Relacje z badań}

M2: No i ja jestem Rosjaninem. Mam rosyjską kulturę. Jaka tam żydowska, jak nic nie wiem, rozumiesz?

M.M.: Stał się Pan w Izraelu bardziej religijny?

M2: Nie, nie było u mnie tego w środku i nadal nie ma.

M.M.: Czyli świąt Pan nie obchodzi?

M2: Nie, no obchodzimy. Na przykład, w mojej rodzinie. W Hajfie mieszkaliśmy wśród religijnych Żydów. No i oni do nas wpadną, my do nich. Widzieliśmy, jak żyją. Sąsiad mi mówi: «Słuchaj, Sioma, dam Ci kipę, pójdziesz ze mną do synagogi!». No to chodziłem z nim. Posłuchałem, jak śpiewają pieśni, to wszystko, no i czułem się jak biały kruk, rozumie Pani? Oni modlą się, coś tam czytają, a ja siedzę jak na szpilkach i nie wiem, co ze sobą zrobić. No i myślę: «Nie będę ich krępował lepiej. Mam do nich szacunek, niech sobie się modlą, zachowują». No ale co, w Jom Kipur u mnie cała rodzina... my tego, nie jemy. Zachowujemy ten...

M.M.: Post?

M2: Nie, Jom Kipur. To żelazne.

Często zachowywane w rodzinach emigrantów z Birobidżanu nakazy i zakazy religijne mają motywację całkowicie niesakralną, tłumaczone są dbałością o zdrowie i wyborem diety odpowiedniej do wieku.

M5: No i po drugie - nie jemy wieprzowiny, w ogóle zrezygnowaliśmy. No bo zdrowie, wątroba zaczęła boleć.

Rozmówcy z najstarszego pokolenia mają poczucie, że społeczeństwo izraelskie ich marginalizuje nie tyle z powodu wieku, co właśnie ze względów językowych i mentalnych. Czują się inni, niedocenieni przez swoich, jak sami mówią, „straceni dla swojej nacji”.

M2: Ja jeszcze się nazywam, jak to mówił Hemingway, stracone pokolenie. Jesteśmy straconym pokoleniem. Dla swojej nacji, dla Żydów. Wszystko nam zniszczyli, nic nie mieliśmy.

Zaczynają się różnić nawet od młodszego pokolenia swoich rodzin, które coraz częściej staje się hebrajskojęzyczne i zatraca znajomość języka rosyjskiego, nie wspominając już o jidysz.

K4: Moja córka ze swoją córką mówi tylko po hebrajsku. My się obrażamy na nią, ale ona tylko po hebrajsku, to jest straszne.

K3: Moja córka, kiedy rozmawia ze mną o pracy, o studiach, jej prościej jest mówić po hebrajsku. Ona do mnie po hebrajsku, a ja po rosyjsku. Wnukowie świetnie czytają, wspaniale mówią po rosyjsku, ale między sobą tylko po hebrajsku. Bardzo się boję, że maluchy stracą język. 
Charakterystyczne jest to, że większość obaw z powodu przerwania przekazu tradycji w rodzinie i odrzucenia języka rodziców (rosyjskiego) przez pokolenie dzieci pojawia się w wypowiedziach kobiet. Być może dlatego, że w tradycji żydowskiej matka jest przekazicielką pochodzenia, a zatem czuje się również odpowiedzialna za transmisję i innych wartości, w tym języka. Problematyka ta musi być w przyszłości wnikliwiej zbadana.

Choć przeprowadzanie wywiadów biograficznych było nadrzędnym celem moich badań, to nie sposób było nie skorzystać z materiałów archiwalnych, które udostępniali mi rozmówcy. Miałam więc okazję poznać archiwa domowe zawierające zdjęcia, spisane autobiografie, wycinki z gazet i pamiątki rodzinne, które dokumentują życie w Birobidżanie od lat 30. XX w. do momentu wyjazdu. Przywiezione do lzraela stały się niewątpliwie przedmiotami organizującymi tożsamość moich rozmówców. Część z zachowanych dokumentów sporządzona była w jidysz, inne po rosyjsku. Zasługują one oczywiście na oddzielną analizę.

\section{Podsumowanie}

Pierwszy etap badań terenowych przyniósł wiele cennych obserwacji, ale nie wszystkie obszary życia emigrantów z Birobidżanu udało mi się udokumentować. Na szczególną uwagę zasługuje działalność organizacji zrzeszających przybyszy z ŻOA, które mają w swoim programie różne sposoby umacniania wspólnoty przez kultywowanie odrębnych tradycji, w tym także języka rosyjskiego. Oprócz tego udało mi się ustalić, że jidysz jako język wspólnotowy nadal funkcjonuje w tym środowisku, pełniąc jednocześnie funkcję prestiżową oraz funkcję języka tajnego.

Kolejna wyprawa terenowa, zaplanowana na sierpień - wrzesień 2013 r., przewiduje spotkanie z najliczniejszą wspólnotą emigrantów z Birobidżanu, zamieszkujących obecnie w miastach Ma'alot oraz Nazaret. Ma’alot jako miasto partnerskie Birobidżanu przyjmowało emigrantów już od końca lat 80., dawało im pracę oraz pomagało w zaadaptowaniu się w zupełnie nowych dla nich warunkach. Obecnie jest nazywane izraelskim Birobidżanem. Wywiady będą prowadzane z przedstawicielami trzech pokoleń: najstarszym (czyli dziećmi dawnych przesiedleńców do Birobidżanu), średnim (ich dziećmi) oraz najmłodszym (pokolenie wnuków). Oprócz tego planuję wziąć udział w corocznym spotkaniu emigrantów z ŻOA we wrześniu 2013 roku w Tel Awiwie oraz dokonać obserwacji uczestniczącej podczas żydowskich świąt jesiennych. 


\section{Bibliografia:}

Hammersley Martyn, Atkinson Paul, 2000, Metody badań terenowych, tłum. Sławomir Dymczyk, Poznań: Zysk i S-ka Wydawnictwo.

Котлерман Майя, Котлерман Михаил (red.), 2010, Весь Биробиджан, Израиль.

Lustiger Arno, 2004, Czerwona księga. Stalin i Żydzi: Tragiczna historia Żydowskiego Komitetu Antyfaszystowskiego i radzieckich Żydów, przeł. Warszawa: W.A.B.

Makarowa Maria, Sawaniewska-Mochowa Zofia, 2010, Społeczność żydowska w Birobidżanie w perspektywie przyszłych badań językowo-kulturowych, w: Silva rerum philogicarum. Studia ofiarowane Profesor Marii Strycharskiej-Brzezinie z okazji Jej jubileuszu, red. Janusz S. Gruchała, Halina Kurek, Biblioteka „LingVariów”, t. 10, Kraków: Księgarnia Akademicka, s. 201-210.

Patek Artur, 1997, Birobidżan. Sowiecka ziemia obiecana? Żydowski Obwód Autonomiczny w ZSRR, Kraków: Historia lagellonica.

Stalin Józef, 1949, Marksizm a kwestia narodowa, w: tegoż, Dzieła, t. 2, Warszawa: Książka i Wiedza.

Zielińska Anna, 2002, Polska mniejszość na Litwie Kowieńskiej. Studium socjolingwistyczne, Warszawa: Slawistyczny Ośrodek Wydawniczy.

http://newswe.com/index.php?go=Pages\&in=view\&id=5313

Ruscy w Izraelu są skazani na bycie obcymi http://inosmi.ru/asia/20110102/165288006.html

\section{"We are the lost generation". Communities of Birobidzhan Jews in Israel: field research report (July 2012)}

In this article I describe the fieldwork conducted in Israel in 2012 among those who have emigrated from the Jewish Autonomous Oblast in Russia. Along with a general overview of the research I present a detailed analysis of my interlocutors' discourses regarding the languages they speak and their attitude towards Judaism and what is commonly understood as Jewishness. I concentrate mainly on the knowledge of Yiddish (which up until now is the official language in Birobidzhan) and Hebrew, and also on the categories that define the Jewish element of identity for them.

\section{Key words:}

Birobidzhan, emigrants, Yiddish, Hebrew, identity

\section{Słowa kluczowe:}

Birobidżan, emigranci, jidysz, hebrajski, tożsamość 